PLURAL, Revista do Programa de Pós-Graduação em Sociologia da USP, São Paulo, v. 16, n. 2, pp. 33-64, 2009

\title{
Práticas sindicais na Toyota do Brasil: os casos de São Bernardo do Campo (SP) e Indaiatuba (SP)
}

\section{Gustavo Takeshy Taniguti*}

Resumo: Este texto analisa as formas pelas quais os sindicatos metalúrgicos de duas unidades produtivas de uma mesma empresa automobilística organizaram suas açóes a partir de um contexto de grandes mudanças, iniciado a partir da década de 1990. São objetos de análise os trabalhadores de duas unidades da Toyota Motors Co. do Brasil: a de São Bernardo do Campo, localizada na região do $\mathrm{ABC}$ paulista, e a de Indaiatuba, localizada na região de Campinas-SP. Procurou-se colocar em discussão as práticas do Sindicato dos Metalúrgicos do ABC, localizado em uma tradicional região industrial, e também as do Sindicato dos Metalúrgicos de Campinas e Região, que representa um novo território produtivo brasileiro. No contexto das recentes transformaçóes ocorridas no setor automotivo brasileiro, especialmente a partir da década de 1990, as estratégias de racionalização do processo produtivo desconfiguraram as formas tradicionais de ação sindical e de organização do trabalho, fazendo com que os atores sociais se repensassem nesse contexto de mudanças.

Palavras-chave: Toyota; reestruturação produtiva; sindicalismo; indústria automobilística; antigos e novos territórios produtivos.

Union practices at Toyota do Brasil: a São Bernardo do Campo and Indaiatuba case study

Abstract: This paper discusses the ways in which workers unions from two brazilian Toyota automobile plants organized their actions in a context of changes, starting from 1990s. I analyse both metalworkers union's practices of $A B C$ paulista region - located in a traditional industrial area - and Campinas metalworkers union - located in a new industrial cluster. In a context of recent changes lived by the brazilian automotive industry, especially from the 1990s, the rationalization strategies in the production processes have been changing traditional

* Mestre e doutorando em Sociologia pelo Programa de Pós-Graduação em Sociologia da Universidade de São Paulo. E-mail: gtaniguti@usp.br. 
forms of union activity and work organization, so these workers and their unions started to rethink their possibilities of action.

Keywords: Toyota; productive reestructuring; trade unionism; automobile industry; greenfields and brownfields.

\section{INTRODUÇÃO'}

Esta pesquisa procura sistematizar uma discussão sobre os trabalhadores e os sindicatos da Toyota do Brasil no contexto recente de abertura de novas plantas produtivas e de transformaçóes na atuação dos sindicatos metalúrgicos, a qual tem início a partir da metade da década de 1990. Dentro desse debate sindical, a atenção se volta para aqueles que representam os trabalhadores da Toyota: o Sindicato dos Metalúrgicos do ABC e o Sindicato dos Metalúrgicos de Campinas e Região. Em ambos os casos, o objetivo é se debruçar sobre as atividades sindicais nessa empresa, relacionando-as a movimentos sindicais mais gerais.

De forma geral, no caso do $\mathrm{ABC}$ paulista, essas atividades se referem a práticas que surgiram como alternativa a um novo contexto da indústria automobilística brasileira, marcado, em grande parte, por demissóes, processos de reestruturação, modernização, adoção de novas tecnologias e pela desterritorialização de unidades produtivas.

Quanto ao Sindicato dos Metalúrgicos de Campinas e Região, as práticas sindicais em questão se referem às suas principais formas de atuação, a partir do crescimento de um novo contingente de trabalhadores diante de um cenário anterior, caracterizado pelo desemprego e por processos de modernizaçáo produtiva.

Argumenta-se que, com o crescimento das atividades da Toyota no Brasil, houve ampliação na atuação sindical de seus trabalhadores, percorrendo, contudo, dois caminhos distintos. Um breve esboço daquilo que se sugere chamar de dois "padróes de sindicalismo" oferece pistas para que se compreendam quais foram as alternativas colocadas em prática por esses sindicatos.

Por um lado, as atividades sindicais na unidade da Toyota de Sáo Bernardo do Campo desenvolveram-se especialmente a partir da metade da década de 1990, acompanhando a tendência de organizaçáo por local de trabalho e negociaçáo por empresa do sindicalismo do ABC. Por outro lado, na unidade da Toyota de Indaiatuba, as atividades sindicais mais expressivas tiveram início no final daquela década e, apesar de ali também haver uma tendência às negociaçóes por empresa, desde os anos I980, a maioria dos temas negociados ainda referia-se aos salários (reajuste, reposição de perdas, aumento real, piso salarial) e às condiçóes de trabalho (refeitório, convênio médico, condições de trabalho insalubres e perigosas, renovação de benefícios sociais) (ArAújo et al., 200I).

Quanto à estrutura de representação interna e à organização sindical, também há diferenças marcantes entre o sindicalismo do $\mathrm{ABC}$ e o de Campinas: no primeiro vigora atualmente um

I Este artigo é resultado parcial da pesquisa "Sindicatos e relaçôes de trabalhos na Toyota do Brasil: São Bernardo do Campo e Indaiatuba em uma perspectiva comparada”, financiada pela FAPESP, a quem agradeço pelo apoio. 
modelo "híbrido" de representação, interno às fábricas, que contempla as comissóes de fábrica e os comitês sindicais de empresa; já no segundo caso, oficialmente não há representação sindical interna, vez que o sindicato atua fora dos portóes das fábricas.

Em um primeiro momento do artigo, introduz-se um debate sobre a indústria automobilística brasileira, localizando a discussão sobre os trabalhadores e seus sindicatos. Em seguida, apresenta-se o contexto geral que envolveu o sindicalismo metalúrgico durante a década de 1990, ressaltando os casos do $\mathrm{ABC}$ paulista e de Campinas.

Com base nos dados da Rais (Relação Anual de Informaçôes Sociais do Ministério do Trabalho), realiza-se uma breve caracterização das regiôes de Campinas e do $\mathrm{ABC}$ paulista, em termos de emprego e máo de obra do setor. Por fim, busca-se demonstrar quais foram as principais ações sindicais mais recentes na Toyota do Brasil.

E quais são os motivos que levam a um estudo sobre os trabalhadores da Toyota do Brasil? Em seguida, procura-se responder a essa questão. Atualmente, o setor automobilístico mundial tem se transformado de forma intensa, especialmente no que se refere à configuraçấo de novos polos produtivos, que se encontram intimamente relacionados à internacionalização desse setor industrial.

Visto sob esse prisma, é possível sistematizar algumas características principais dessa nova realidade, que são, segundo Garcia (2006): aproximação entre blocos regionais, prospecção de mercados emergentes, busca por vantagens territoriais, aquisiçôes e fusōes entre montadoras, novos arranjos com fornecedores, modelos mundiais e novos conceitos produtivos.

Atravessados pelo eixo global-nacional-local, para esse autor, os recentes estudos sobre o tema revelam novas questốes de pesquisa. Os estudos, para fins analíticos, podem ser classificados em três grandes tendências: a) razôes e condiçóes da instalação das novas unidades industriais; b) novos conceitos aplicados à organizaçáo e à gestáo das plantas e suas implicaçóes para os trabalhadores, em termos dos requisitos de qualificação ou de competência, das condiçôes de trabalho, da subjetividade do trabalho; c) repercussóes regionais dos novos investimentos, em termos de reestruturaçáo dos fornecedores locais e de mudanças nas relaçóes de trabalho.

Em estudos de caso sobre montadoras, o debate sobre sindicalismo metalúrgico pode ser localizado na última das tendências apontadas, referindo-se, portanto, a um fenômeno de ordem local, uma vez que é circunscrito pela representaçáo territorial de cada sindicato. Além disso, vale lembrar que o debate de ordem regional também se faz presente, especialmente quando se considera o movimento de investimentos das empresas automobilísticas partindo de antigas para novas localidades. Nesse sentido, o caso da Toyota do Brasil é bastante ilustrativo.

Elegeram-se como objeto de análise os trabalhadores da empresa que, por seu pioneirismo, tornou-se emblemática no que se refere a formas de gestáo da produção: a Toyota. Mas, apesar de essa empresa ter sido objeto de vários estudos no âmbito acadêmico internacional nas últimas três décadas, cabe ressaltar que esta pesquisa em específico se apoia em uma lacuna observada na literatura da Sociologia do trabalho brasileira. 
Com exceção de Lima (2006), aponta-se para o fato de que há, até o presente momento, poucos estudos de caso dedicados à Toyota do Brasil que contemplem questóes sobre os sindicatos metalúrgicos e o cotidiano de seus trabalhadores ao longo da trajetória dessa empresa no país. Parte da ausência de estudos de caso sobre as atividades da Toyota do Brasil se deve a algumas particularidades. Em seguida, sugerem-se quais seriam elas.

A primeira unidade produtiva internacional da empresa (ou seja, fora do Japão) foi instalada em 1958, no município de São Paulo. Quatro anos mais tarde, em 1962, no município de Sáo Bernardo do Campo (SP), foi inaugurada outra unidade produtiva, dedicada à fabricaçáo do veículo Bandeirante. Dando início a um novo período de investimentos, somente no ano de 1996 essa planta sofreu um processo intenso de reestruturaçáo produtiva, ou seja, quase trinta e cinco anos após sua chegada ao Brasil.

No ano de 1998, uma nova unidade produtiva foi criada no município de Indaiatuba (SP), com investimentos de cerca de trezentos milhóes de dólares. No ano de 2008, a empresa anunciou a criaçáo de uma futura unidade de produçáo no município de Sorocaba (SP), com investimentos estimados em cerca de um bilhão de dólares. A atual baixa participaçáo da Toyota na produçáo do mercado interno de veículos (cerca de cinquenta e seis mil veículos produzidos em 2007 ou $2,34 \%$ do total) e a implantaçáo tardia de formas de gestáo e novas tecnologias em uma nova unidade produtiva talvez expliquem, em partes, a escassez de estudos dedicados aos trabalhadores dessa empresa, hoje em um número total de cerca de três mil e trezentos ${ }^{2}$, distribuídos em duas unidades produtivas e em dois escritórios administrativos.

Apenas recentemente a Toyota tornou-se representativa na produçáo de veículos de passeio no mercado brasileiro, sendo possível constatar que há um intervalo de décadas desde a chegada da empresa ao Brasil até a inauguração de plantas "enxutas" sob o formato de gestão do STP (Sistema Toyota de Produçáa). Do ponto de vista das relaçóes de trabalho estabelecidas no âmbito da produção, essa distância se apresenta como práticas sociais construídas de formas distintas em São Bernardo do Campo e em Indaiatuba. Sob esse ponto de vista, trata-se de diferenças que parecem reverberar, então, como uma tensão.

Além de questóes relacionadas à dinâmica do setor, gestáo da produçáo, cadeias produtivas e políticas industriais, entre outras, essa ampliação das atividades da Toyota do Brasil coloca em discussão a representação sindical de seus trabalhadores, especialmente por dois motivos, que parecem apontar para uma ampliaçáo das açóes sindicais: a) se comparada às grandes empresas do setor, até o ano de 1996, a organizaçáo sindical dos trabalhadores da unidade da Toyota de São Bernardo do Campo era bastante limitada, fato que passa a mudar com o anúncio da criaçáo de uma nova montadora da empresa e da subsequente reestruturação dessa planta; b) a partir de 1999, na unidade da Toyota de Indaiatuba, o movimento sindical de seus trabalhadores se tornou atuante, apesar da inexistência de formas de organização sindical internas à empresa.

Assim, algumas questóes podem ser levantadas: quais foram os caminhos percorridos pelos sindicatos metalúrgicos diante das dificuldades encontradas durante a década de 1990? Quais os

2 Fonte: Anfavea. Dados não publicados. 
impactos que a abertura de novas plantas produtivas teve para a ação sindical de antigas e novas localidades? Quais foram as demandas e as açóes dos trabalhadores da Toyota nesse período? Procurou-se, no decorrer do artigo, encontrar as respostas para tais questóes.

Inicialmente, é útil realizar uma breve caracterização das mudanças ocorridas na indústria automobilística brasileira, a partir da década de 1990 , e também demonstrar a interpretação de uma literatura sobre esses acontecimentos. Por meio disso, é possível identificar como tais mudanças tiveram impacto na organização do movimento sindical, especialmente na mobilização de suas bases e na transformação das relaçóes de trabalho.

\section{MUDANÇAS NAS RELAÇÕES DE TRABALHO DA INDÚSTRIA AUTOMOBILÍSTICA}

É possível afirmar, de forma geral, que na década de 1990 a indústria automobilística emergiu novamente no âmbito da produção industrial como um passaporte para a modernizaçáo da economia do país. Diferentemente da década de 1960, dessa vez ela esteve acompanhada pelo discurso da "reestruturaçáo" e pela disseminaçáo de um vocabulário extenso, intimamente ligado às novas tecnologias, às novas formas de gestão da produção e aos novos encadeamentos produtivos: Just-In-time, Kanban, Kaizen, Círculos de Controle de Qualidade, flexibilização, multifuncionalidade, lean production. Tais mudanças sofridas pela indústria automobilística podem ser compreendidas como estratégias de racionalizaçáo do processo produtivo que acompanham historicamente as empresas do setor, de forma que "são constantes as mudanças que visam aumentar a produtividade e atender as demandas do mercado" (RodRigues; RAMALHO, 2007).

Vários foram os estudos da Sociologia do trabalho brasileira que, na década de 1990, procuraram desvendar como essas formas de gestáo passaram a ser aplicadas na indústria nacional (Bernardes, I99i; Hirata, I993; Salerno, I994; Castro, I995; Leite, I997; Araújo; Gitahy, i998; Arbix; Zilbovicius, i997; Leite; Rizek, I997; Gitahy; Bresciani, i998; Abreu et al., I998; CARDOSO, I999).

No se refere a dinâmicas organizacionais, a novidade parece residir atualmente em uma transfiguração em âmbito mundial, em que as empresas, com base em dois elementos-chave de competitividade (inovaçáo e internacionalizaçáo das relaçóes com fornecedores e de investimentos), realizam alianças entre montadoras, promovem fusóes e aquisições de companhias, modularizam a produção e projetam integração entre fornecedores globais (GARCIA, 2006).

A partir da década de I980, a indústria automobilística brasileira já ensaiava movimentos de reestruturaçáo produtiva setorial perante a crise econômica da chamada "década perdida". Em I98I, a produção de veículos apresentou uma queda de $33 \%$ com relaçáo ao ano anterior, e o emprego nas montadoras apresentou queda de 30\% no mesmo período. Os investimentos das montadoras, por sua vez, cresceram 32\% entre i980 (US\$ 519.667) e 198I (US\$ 670.710) (CARdoso, 2000), representando estratégias de direcionamento de parte da produçáo para o mercado externo. Ou seja, esses investimentos buscaram maior penetração no mercado externo 
(em média $22 \%$ das vendas totais de veículos entre 1980 e 1985 ), priorizando a qualidade dos produtos e novas tecnologias brandas incidentes.

Cardoso (2000, p. 43) afirma que tais investimentos foram suficientes apenas para "sustentar vendas externas defensivas e excepcionais".

Já no final dessa mesma década foi assinado o Tratado de Integração, Cooperaçáo e Desenvolvimento entre Brasil e Argentina, um acordo bilateral que fixou como meta o estabelecimento de um mercado comum, no qual outros países latino-americanos poderiam se unir, o que de fato ocorreu em I99I, com a adesão do Paraguai e do Uruguai, dando origem ao Mercado Comum do Sul (Mercosul).

Sumariamente, os impactos do acordo bilateral para o setor automotivo e da abertura externa obrigaram as montadoras a modernizar as tecnologias do processo de produçáo, visando, assim, a se adequar às tendências mundiais. Isso significa que o modelo de industrialização até entáo fundamentado no mercado cativo passou a ser pensado em termos regionais e, posteriormente, globais 3 . O complexo automotivo brasileiro, defasado em termos tecnológicos, se comparado aos modelos das matrizes mundiais, agora enfrentava as novas exigências colocadas pela regionalizaçáo e pela expansão global em termos de competitividade. Abriu-se, portanto, a possibilidade de articulação entre mercado interno e externo, que, em períodos anteriores, era bastante restrita.

A reaçáo das montadoras com relação a esse novo contexto foi visar a sua sobrevivência a longo prazo, e, nesse sentido, a experiência da Câmara Setorial Automotiva ${ }^{4}$, iniciada em I99I, recebeu grande atençáo por parte das empresas, do Estado e dos trabalhadores, espantando as previsōes mais pessimistas. No entanto, tal experiência foi abandonada em 1995, no início do primeiro governo de Fernando Henrique Cardoso.

Um aspecto a ser ressaltado é que, em I995, o déficit comercial foi de US $\$ 3,3$ bilhóes ou 2,5\% do PIB (IPEA, 1997). Por isso, em março do mesmo ano, junto com o Novo Regime Automotivo, uma Medida Provisória aumentou a alíquota de importaçáo de $20 \%$ para $70 \%$, favorecendo as montadoras já instaladas no país. Com isso, o governo procurou aliviar a balança comercial. A partir daquele ano, novas políticas industriais regulatórias tomavam rumos com o Novo Regime Automotivo (NRA), criado a partir da Medida Provisória 1.024, de 13/06/1995.

O NRA se constituiu como uma política industrial setorial, obtendo êxito na atração de investimentos (aderiram ao regime dezesseis grandes montadoras, cento e cinquenta empresas de autopeças e vinte e nove firmas de outros setores produtivos), e até o ano de 2002, dezessete empresas ${ }^{\zeta}$ instalaram novas unidades no país. Entre 1995 e 1996, cerca de US $\$ 4$ bilhóes foram

3 Para mais informaçóes sobre políticas industriais do setor automotivo, consultar Bedê et al. (1997).

4 As Câmaras Setoriais - criadas em 1989 e desativadas em 1995 - foram um arranjo institucional que teve como objetivo promover a discussão de medidas de política industrial setorial, a serem promovidas pelo governo federal. Para mais informaçôes sobre a Câmara Setorial da Indústria Automobilística, consultar Arbix (1997) e Anderson (1999). 5 As empresas que instalaram novas unidades no Brasil entre os anos de 1995 e 2006 foram: Volvo (I995) em Pederneiras (SP); Volkswagen Caminhōes e Ônibus (1996) em Resende (RJ); Honda (1997) em Sumaré (SP); International (I998) em Caxias do Sul (RS); Mitsubishi (I998) em Catalão (GO); Toyota (I998) em Indaiatuba (SP); Daimler Chrysler (1999) em Juiz de Fora (MG); Land Rover (1999) em São Bernardo do Campo (SP); Renault (1999) em São José dos 
aplicados por empresas como a Volkswagen, a Honda, a Mitsubishi, especialmente na renovaçáo de unidades de produção, construçáo de novas fábricas, introdução de novas tecnologias de ponta, dando início a vários processos de reestruturaçáo produtiva do setor com base na ideia norteadora de produçáo "enxuta".

Sobre esse debate, autores constataram que, apesar de a redução das desigualdades regionais se constituírem como um dos objetivos do NRA, em vez de os investimentos serem direcionados para as regióes Norte, Nordeste e Centro-Oeste, o movimento foi, predominantemente, rumo ao Sul e Sudeste, visto seus governantes terem obtido mais sucesso na oferta de benefícios (Arbix, 2002).

Desencadeando uma intensa disputa fiscal que envolveu estados e municípios, viu-se que a atração de novos investimentos por empresas do setor automotivo foi bem-sucedida durante a vigência do NRA. Mas, por outro lado, o universo do trabalho e dos trabalhadores náo foi contemplado por tais políticas (Zilbovicius; ARBiX, I997; CARDOSo, 2000; ARBIX, 2002), e o discurso que alimentava a constituiçáo de novas institucionalidades constantemente condenava a ação dos sindicatos.

Para esses personagens, o horizonte de possibilidades parecia traduzir-se no desfecho de um ciclo de renovação, a partir do chamado "novo sindicalismo", para a abertura de outro, caracterizado pela desregulamentaçáo.

Processos de reestruturaçấo produtiva das montadoras, ainda que considerados caso a caso, passaram a compor o quadro de estratégias de concorrência das grandes empresas, na metade da década de 1990. Além disso, os novos investimentos em plantas "enxutas" foram assimétricos por conta dos privilégios que foram concedidos às montadoras, em detrimento do restante da cadeia automotiva, como o setor nacional de autopeças e os trabalhadores (durante o NRA, máquinas e equipamentos poderiam ser importados com alíquota zero, e as autopeças com alíquota inicial de $2 \%$ ).

Outros descompassos puderam ser observados em termos de absorção de mão de obra do setor, que passou a se transformar no que se refere à proporcionalidade entre produção e emprego. Desde a década de 1980, o aumento da produçáo sempre significou o crescimento dos empregos, quadro que passou a mudar após 1995, como afirma Cardoso (2000, p. 6I): "o aumento da produção não é acompanhado de aumento no número de empregados no complexo como um todo. Ao que parece, 1995 marca, definitivamente, o momento de não-retorno da reestruturação sistêmica do setor automotivo brasileiro".

Do ponto de vista das relaçóes de trabalho nas montadoras, os novos arranjos produtivos, considerados em seu nível da "prática" (Zilbovicius, I999, contribuíram para promover movi-

Pinhais (PR); Volkswagen-Audi (I999) em São José dos Pinhais (PR); John Deere (1999) em Catalão (GO); CNH Case (1999) em Piracicaba (SP); Iveco-Fiat (2000) em Sete Lagoas (MG); General Motors (2000) em Gravataí (RS); Ford (200I) em Camaçari (BA); Peugeot Citroën (200I) em Porto Real (RJ); Nissan (2002) em São José dos Pinhais (PR). Fonte: BNDES (2008). 
mentos de mudança na divisão e no conteúdo do trabalho no ambiente interno das fábricas, assim como na composição da mão de obra das empresas.

Entre essas mudanças, podemos destacar: a hierarquização das qualificações, implicando na construção de um novo perfil de trabalhador, agora multifuncional; a elevação da escolaridade e a proliferação dos programas de treinamento; a diminuição das hierarquias internas dos cargos nas fábricas; a implantação de grupos semiautônomos; os sistemas participativos que procuram envolver o trabalhador; a redução do quadro de funcionários; a exigência de maior escolaridade, maior capacidade de adaptação às novas tecnologias e novas formas de organização da produção; reconfiguração das relações das empresas com os trabalhadores e sindicatos (Zilbovicius, I999; Rodrigues; Ramalho, 2007).

Essas mudanças na organização do trabalho, se comparadas a períodos anteriores, especialmente no período de 1960 a I980, no caso brasileiro, são bastante significativas e permitem dizer que, devido ao ineditismo dos próprios arranjos organizacionais - ou seja, considerando que estes são objetos historicamente construídos em determinadas condiçóes -, representam mudanças substantivas relacionadas ao trabalho nos "chãos-de-fábrica", desdobrando-se também em desafios para os sindicatos:

as mudanças técnico-organizacionais e o ambiente de integração produtiva e comercial, ao afetar de variadas formas tanto o mercado de trabalho como o perfil da força de trabalho, reserva efeitos profundos sobre as formas de organização e de representação de interesses dos trabalhadores (CARDoso et al., 1997, p. 438).

A partir do enfoque sobre a organização sindical, para esses últimos autores, tais transformaçóes passaram a afetar as bases de sustentação dos sindicatos metalúrgicos em pelo menos três aspectos: reduzindo sua base quantitativa; mudando o perfil de qualificação dos trabalhadores; e introduzindo modelos de gestão da força de trabalho.

A redução das bases dos sindicatos metalúrgicos a partir daquilo que consideramos o novo contexto do setor automotivo representou um novo desafio ao sindicalismo do ABC paulista, que, nas décadas de 1970 e 1980 , era caracterizado pelo confronto. Nessa regiáo se concentra atualmente $35 \%$ da produçáo de automóveis no país, e a taxa de sindicalização atingia até 90\% em montadoras como a Mercedes-Benz (Rodrigues, I997).

Para Cardoso, Comin e Campos (I997), a possibilidade de sobrevivência dos sindicatos brasileiros estaria relacionada à sua capacidade de romper com a dualidade da estrutura sindical (a emergência do sindicalismo mobilizador e sua dependência da legislação corporativista), observada no período, por meio de açóes visando a organizar contingentes expressivos de trabalhadores.

A questão central para os autores foi avaliar até que ponto as mudanças nas bases sociais do sindicalismo poderiam ou não colocar em risco o poder sindical, tal como era praticado. Como conclusão, afirma-se que a reduçáo no contingente absoluto dos trabalhadores empregados na indústria automobilística na região do ABC, entre I986 e 1994 (de 89.502 para 66.927, ou seja, 
uma queda de $35,2 \%$ ), não significou necessariamente o enfraquecimento dos sindicatos. Seria possível, no caso do $\mathrm{ABC}$, que se estivesse diante de uma tendência à microrregulação nas relaçóes capital-trabalho, a exemplo das comissões de fábrica ${ }^{6}$.

Para além da discussão das formas de gestão que passaram a compor as estratégias de produção das montadoras no período, vale ressaltar que as formas organizacionais isoladamente não explicam mudanças nas relaçóes de trabalho. No universo fabril também estão presentes, como diria Burawoy (1985, p. 87), os “aparatos da política de produção", ou seja, as instituiçóes que regulam e modelam os conflitos nos locais de trabalho.

Haveria, portanto, o inter-relacionamento entre política de produção e política do Estado. Podemos entender, assim, o mundo do trabalho como uma construção social, em que existem mediaçóes e agenciamentos da vida cotidiana que operam como condensação de práticas e relaçóes diversas. Nesse universo de análise, diversos atores - entre eles Estado, empresas, trabalhadores e sindicatos - são capazes de negociar e compartilhar experiências políticas, econômicas e sociais.

Nesse sentido, o trabalho de Rodrigues e Martins (I999) é bastante elucidativo, ao demonstrar a complexidade e a heterogeneidade do debate sindical sobre as mudanças nas relaçóes de trabalho em meados da década de 1990. Os autores afirmam que houve, no período, a ampliação do escopo da negociaçáo direta entre patróes e empregados, ou seja, haveria entre esses dois polos uma pluralidade de elementos importantes, como, por exemplo: os padróes distintos de ação sindical dos metalúrgicos de São Paulo, representados pela Força Sindical, e dos metalúrgicos do ABC paulista, representados pela Central Única dos Trabalhadores (CUT); a ação direta do Estado por meio da Medida Provisória da Participação dos Trabalhadores nos Lucros e Resultados, editada em 29 de dezembro de 1994, que promoveu inovaçóes significativas no âmbito das relaçóes capital/trabalho, trazendo a negociação coletiva para o âmbito da empresa.

Do ponto de vista das atividades sindicais da década de I990, esses últimos autores afirmam que houve, de fato, uma tendência às negociaçóes por empresa:

Em função das transformações que ocorreram na economia, na política e, em alguma medida, na sociedade, a agenda sindical se voltou para o interior da empresa, discutindo mais diretamente questôes relacionadas com a problemática do trabalho, sejam as vinculadas à organização e gestão do trabalho, sejam aquelas ligadas à remuneração variável (Rodrigues; MarTins, I999, p. I66).

Já Cardoso (1999) constata que, apesar de o sindicalismo brasileiro ser fragmentado, descentralizado e manter traços gerais da "velha estrutura" corporativista, tal fragmentação também

6 A partir de 198I, o Sindicato dos Metalúrgicos do ABC conseguiu implantar formalmente comissóes de fábrica ou delegados sindicais, com garantias de emprego. Até 1996, elas existiam em quarenta e quatro empresas do polo automobilístico da região (BRESCIANI, 1997). As comissōes de fábrica só foram consolidadas depois de mobilizaçóes sindicais, como a greve que resultou na criação da Comissão da Ford (SP), em 198I (para mais detalhes, consultar Rodrigues, I99I). Posteriormente, no ano de 1999, as comissóes de fábrica passaram a coexistir com os Comitês Sindicais de Empresa, conforme deliberado no $3^{\circ}$ Congresso dos Metalúrgicos do ABC. 
é sinônimo de organização de interesses, e não de fragilidade do movimento sindical. Ou seja, apesar de a estrutura sindical combinar conservação e mudança, ela possui um dinamismo inovador na ampliação quantitativa e qualitativa da prática sindical.

Entre as diversas conclusóes sobre o sindicalismo brasileiro na década de 1990, uma delas pareceu unânime na literatura: a constataçáo de que os trabalhadores metalúrgicos e seus respectivos sindicatos foram pressionados por uma nova conjuntura, tanto nos "chãos de fábrica", isto é, no espaço micro-organizacional, quanto fora deles.

Pesquisadores apontavam a existência de uma "nova contratualidade" entre os principais atores envolvidos no complexo automotivo, isto é, a relaçáo dos sindicatos com as empresas estaria passando de um tipo "conflitivo de anulaçáo" a uma "relaçáo conflitiva de reconhecimento mútuo". Nos países centrais, especialmente na Europa, o declínio da participação dos sindicatos nas questôes relacionadas ao trabalho parecia ser um processo de difícil retorno, que anunciava a "crise" do sindicalismo (Rodrigues, I999).

As especificidades e as recentes formas de atuação dos sindicatos analisados nesta pesquisa permitem demonstrar alguns aspectos que vão em direção contrária ao debate sobre a "crise", ao observarmos que o espaço para a organização sindical no setor automotivo brasileiro tem revelado novas formas de participaçáo política e de negociação. Emprestando a tese de Hyman (1997), pode-se argumentar que o que ocorre não é propriamente a desagregaçáo, a divisão e o fim do sindicalismo solidário, mas sim uma crise de orientaçôes tradicionais do sindicalismo, sendo necessário considerar, por exemplo, mudanças geracionais e de orientaçáo dos trabalhadores (Pialoux; Beaud, 2009).

Se avançarmos até os recentes estudos de caso sobre trabalhadores de novos (no caso do Sul fluminense e do Paraná) e antigos locais produtivos (no caso do ABC paulista) do setor automotivo, o que se constata é que os trabalhadores e os sindicatos dessas localidades "têm se posicionado de modo a ampliar o seu escopo de atuação assumindo novas responsabilidades e repensando seu modo de atuação" (Rodrigues; RamalHo, 2007, p. 39).

No caso paranaense, Araújo (2007) afirma que o sindicato tem enfrentado dificuldades diante dos arranjos institucionais e produtivos locais e que "a ação coletiva reduz-se a negociaçôes parcelares e a pautas de reivindicação pontuais e reincidentes" (ARAújo, 2007, p. I57), fazendo com que o movimento sindical passe a reconhecer outros atores coletivos em espaço de negociação, como agências governamentais e privadas de intermediação.

Consideradas caso a caso, conforme a localidade, as empresas analisadas, o perfil do trabalhador e as diferentes propostas defendidas pelos sindicatos, os estudos mencionados procuram trazer novas questôes para discussão, contribuindo para reconsiderar o declínio do sindicalismo entendido como um debate encerrado. Mais do que isso, dada a tendência mais geral de organizaçáo sindical que se caracteriza pelas negociaçôes por empresa, é necessário estar atento às diversas formas de atuação sindical existentes.

Como veremos mais adiante, os trabalhadores da Toyota de Sáo Bernardo do Campo e de Indaiatuba procuraram estabelecer novas formas de organizaçáo coletiva, a partir de meados da 
década de 1990, justamente no mesmo período em que o declínio do sindicalismo aparecia na literatura e nos discursos como uma tendência inevitável. Ao mesmo tempo, as questóes relativas ao trabalho nas montadoras ganharam novas características, e contingentes de trabalhadores em novas localidades passaram a surgir, trazendo novos elementos de análise para os pesquisadores.

Após essas consideraçóes, procura-se, em seguida, caracterizar a composição do emprego na indústria automobilística dos dois municípios analisados, entre os anos de 1998 a 2008, assim como demonstrar a evoluçáo do emprego nas regiōes do $\mathrm{ABC}$ paulista e da Regiáo Metropolitana de Campinas.

A partir disso, torna-se possível verificar quais são os principais atributos da mão de obra metalúrgica sobre a qual este estudo pretende se debruçar e como se comportou o setor automotivo em termos de emprego.

\section{CARACTERIZAÇÃO DOS TRABALHADORES METALÚRGICOS}

É importante ressaltar que os dados utilizados, a partir de elaboração própria da Relação Anual de Informaçóes Sociais (RAIs) do Ministério do Trabalho e Emprego (MTE), estáo limitados a trabalhar com algumas variáveis, como sexo, idade, escolaridade, porte das empresas, entre outras.

Foi utilizado o Código 34 da Classificação Nacional de Atividades Econômicas 95 (CNAE), além das variáveis individuais, geográficas e de estabelecimentos disponíveis. Pesquisas mais detalhadas podem fazer uso de surveys elaborados para fins específicos, utilizando indicadores sociodemográficos como: alocação funcional, ocupação na empresa, participaçáo de assembleias e greves, índices de proximidade com o sindicato, entre outros, como é possível verificar no estudo de Cardoso, Comin e Campos (1997).

Considerando as dificuldades de se realizar uma pesquisa aprofundada sobre os trabalhadores metalúrgicos com a permissão da Toyota do Brasil, a exposiçáo dos dados a seguir pretende estabelecer um perfil mais geral e sintético dos trabalhadores metalúrgicos da Toyota de São Bernardo do Campo e de Indaiatuba.

As questóes relacionadas à filiação sindical, participação em assembleias, ou seja, de atividades sindicais, foram exploradas por meio de entrevistas com trabalhadores, cipeiros e dirigentes sindicais.

No período de 1998 a 2008, a atividade do setor automotivo refletiu, em grande medida, uma expansão dos investimentos feitos durante o NRA. No ano de 2007, o Brasil foi o sétimo maior produtor de veículos do mundo, contando com vinte e sete montadoras e quarenta e nove plantas industriais abastecidas por mais de seiscentas empresas de autopeças.

Seu complexo industrial possuía, no momento, capacidade instalada para produzir 3,5 milhôes de veículos por ano. A participação do setor automotivo sobre o PIB industrial chegava a 22,I\%, e a participação sobre o PIB total do país somava 5,4\%. Apenas em 2008, as montadoras 
investiram cerca de US $\$ 5$ bilhóes, aumentando a capacidade de 3,5 milhóes para cerca de 3,8 milhôes de veículos/ano.

Segundo estimativas da Anfavea (Associação Nacional dos Fabricantes de Veículos), o ciclo total de investimentos alcançaria o patamar de US\$ 20 bilhôes nos próximos três anos, o que inclui a cadeia de fornecedores?. As empresas associadas à ANFAVEA responderam, em 2007, pela geraçáo de 120 mil postos de trabalho direto.

Ainda que atualmente o aumento da quantidade de efetivos tenha, em alguma medida, afastado as previsóes mais pessimistas, diferentemente do que aconteceu em décadas anteriores, a dinâmica do mercado de trabalho desse setor passou a privilegiar — como tendência trabalhadores majoritariamente do sexo masculino, mais jovens e com maior instruçáo formal. Isso é válido tanto para o caso do $\mathrm{ABC}$ quanto para Campinas, como será apresentado adiante.

$\mathrm{Na}$ regiáo do $\mathrm{ABC}$ paulista, no ano de 1988 , o número total de trabalhadores empregados formalmente no setor era de 76.767. Uma década depois, em 1998, os trabalhadores somavam 59.714 , havendo reduçáo de 22,2\% em relaçáo ao primeiro ano. A reduçáo desse contingente pode estar relacionada diretamente aos processos de racionalização produtiva (CARDOso et al., 1997) e ao contexto de organizaçáo das relaçóes de trabalho industrial do período (Rodrigues; MarTins, 1999).

Para Conceiçáo (2007), a abertura comercial, a intensificaçáo do global sourcing e o surgimento de novos polos automotivos contribuíram para a queda no nível dos empregos no ABC.

Entre 1989 e I999, também houve mudanças no perfil das fábricas de autopeças no que se refere ao porte da empresa. Elas estariam mais "enxutas", ou seja, empregariam uma quantidade menor de trabalhadores, porém buscando maiores índices de produtividade. Além disso, houve crescimento do número de empresas do setor, porque a maior parte dos fornecedores globais "teve que instalar unidades de produçáo próximas às unidades de montagem de veículos, de acordo com a política de follow sourcing, posta em curso pelas montadoras" (CoNCEIÇÃo, 2007, p. 318).

Somente após 1999, com a valorizaçáo cambial, houve a reduçáo da defasagem do preço dos produtos nacionais em relação aos importados, o que gerou uma ligeira recuperaçáo do crescimento dos empregos. Além disso, parte da capacidade ociosa das montadoras foi ocupada com a produção de automóveis destinados à exportação.

Segundo o Gráfico I, é possível verificar que houve um ligeira estabilidade de empregos na indústria automobilística do $\mathrm{ABC}$ paulista até o ano de 2003, quando houve queda de 3,1\% no número de empregados. A retomada do setor, ancorada pelo mercado interno, teve início em 2003, acompanhando o crescimento geral de empregos na indústria de transformaçáo, como é possível verificar na Tabela 2.

Inicialmente, o principal motor do processo foi o crescimento sustentado da economia, como mudanças institucionais que afetaram a concessão de crédito e a queda dos juros que impulsionaram o mercado (BNDES, 2008).

7 Fonte: Bndes (2008). 


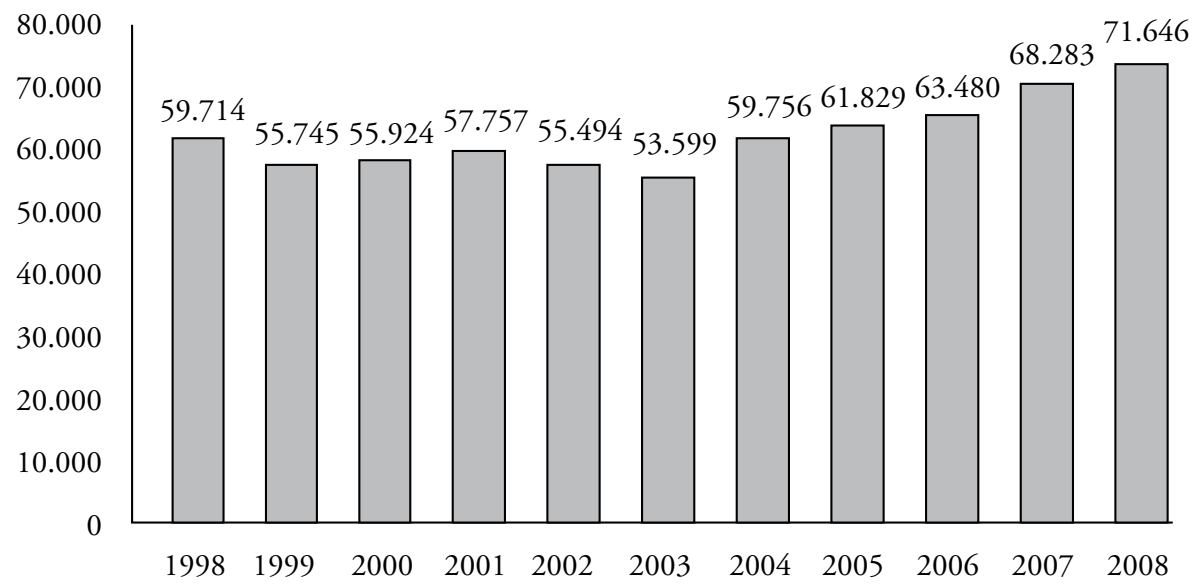

Gráfico 1. Evolução do emprego na indústria automobilística do ABC paulista, 1998-2008. Fonte: Elaboração própria a partir do banco de dados on-line da RAIS/MTE.

Tabela 1. Evolução do emprego: indústria de transformação e indústria automobilística do ABC paulista, 1998-2008.

\begin{tabular}{ccccc}
\hline & \multicolumn{2}{c}{ Indústria de transformaçáo } & \multicolumn{2}{c}{ Indústria automobilística } \\
\hline Anos & Empregos & $\begin{array}{c}\text { Taxa de crescimento } \\
\text { \% }\end{array}$ & Empregos & $\begin{array}{c}\text { Taxa de crescimento } \\
\text { \% }\end{array}$ \\
\hline 1998 & 190.448 & $-13,1$ & 59.714 & $-18,7$ \\
1999 & 185.428 & $-2,6$ & 55.745 & $-6,6$ \\
2000 & 191.276 & 3,1 & 55.924 & 0,3 \\
2001 & 191.189 & $-0,1$ & 57.757 & 3,3 \\
2002 & 189.449 & $-0,9$ & 55.494 & $-3,9$ \\
2003 & 190.164 & 0,4 & 53.599 & $-3,1$ \\
2004 & 210.034 & 10,5 & 59.756 & 11,5 \\
2005 & 218.118 & 3,8 & 61.829 & 3,4 \\
2006 & 225.304 & 3,3 & 63.480 & 2,7 \\
2007 & 238.183 & 5,7 & 68.283 & 7,5 \\
2008 & 247.250 & 3,8 & 71.646 & 4,9 \\
\hline
\end{tabular}

Fonte: Elaboração própria a partir do banco de dados on-line da RaIs/MTE. 
Os processos de enxugamento de mão de obra, assim como os critérios de contrataçáo, têm se tornado cada vez mais seletivos, em termos de grau de instrução e idade. É possível verificar que houve uma mudança significativa no perfil do trabalhador metalúrgico no $\mathrm{ABC}$ : trata-se de jovens, empregados majoritariamente com cursos profissionalizantes e com maior grau de instrução, se comparados com aqueles trabalhadores que estiveram à frente das lutas trabalhistas do final da década de 1970 e da década seguinte (Rodrigues, 2002).

$\mathrm{Na}$ Tabela 3, referente ao município de São Bernardo do Campo, é possível verificar que o envelhecimento da máo de obra tem se concentrado nas faixas etárias acima dos cinquenta anos, apontando para uma possível tendência à estabilizaçáo no emprego. Outra tendência, mais visível, repousa no aumento do nível de escolaridade do trabalhador, que, entre os operários, tende cada vez mais a se concentrar no ensino médio. Em cargos de chefia e administração, houve um crescimento do número de empregados com nível superior completo e pós-graduaçáo (mestrado ou doutorado).

Outro aspecto importante é uma desconcentração do número de trabalhadores de grandes empresas, com mais de quinhentos funcionários, para pequenas (até noventa e nove) ou médias empresas (até quatrocentos e noventa e nove). Isso significa que, ao contrário de outros períodos de desenvolvimento industrial em São Bernardo do Campo, é possível que as empresas do setor

Tabela 2. Evolução da composição do emprego: indústria automobilística de São Bernardo do Campo - 1998-2008.

$1998199920002001200220032004200520062007 \quad 2008$

\begin{tabular}{|c|c|c|c|c|c|c|c|c|c|c|c|}
\hline \multicolumn{12}{|l|}{ Faixa etária } \\
\hline 18 a 29 & 23,9 & 22,7 & 23,4 & 21,9 & 21,8 & 21,17 & 23,1 & 22,2 & 21,6 & 23,5 & 24,3 \\
\hline 30 a 49 & 70,4 & 70,8 & 69,9 & 70,8 & 71,3 & 71,37 & 68,5 & 68,5 & 68,2 & 64,7 & 63,0 \\
\hline 50 ou mais & 5,7 & 6,4 & 6,7 & 7,3 & 7,0 & 7,46 & 8,4 & 9,3 & 10,3 & 11,8 & 12,7 \\
\hline \multicolumn{12}{|l|}{ Sexo } \\
\hline Masculino & 93,8 & 93,3 & 92,8 & 93,0 & 92,6 & 92,1 & 92,9 & 92,1 & 92,0 & 91,7 & 91,2 \\
\hline Feminino & 6,3 & 6,7 & 7,2 & 7,0 & 7,4 & 7,9 & 7,1 & 7,9 & 8,0 & 8,4 & 8,8 \\
\hline \multicolumn{12}{|c|}{ Grau de instruçáo } \\
\hline $1^{\mathrm{a}}$ a $4^{\mathrm{a}}$ série & 15,9 & 14,3 & 10,9 & 9,9 & 8,8 & 4,6 & 7,5 & 6,2 & 5,2 & 4,3 & 3,8 \\
\hline $5^{\mathrm{a}}$ a $8^{\mathrm{a}}$ série & 36,2 & 35,1 & 33,6 & 32,9 & 31,8 & 16,3 & 27,2 & 20,5 & 19,0 & 17,0 & 15,5 \\
\hline $1^{\circ}$ a $3^{\circ}$ colegial & 25,0 & 25,6 & 29,0 & 30,8 & 32,5 & 55,9 & 39,6 & 43,8 & 45,0 & 48,7 & 50,3 \\
\hline Sup. inc. a compl. & 22,9 & 25,0 & 26,5 & 26,4 & 26,9 & 23,2 & 25,7 & 29,5 & 30,8 & 29,9 & 30,3 \\
\hline pós-graduação & 0 & 0 & 0 & 0 & 0 & 0 & 0 & 0 & 0,1 & 0,14 & 0,1 \\
\hline \multicolumn{12}{|c|}{ Porte das empresas } \\
\hline até 99 & 1,2 & 1,1 & 1,5 & 1,5 & 1,6 & 1,8 & 2,1 & 2,5 & 2,7 & 2,6 & 2,8 \\
\hline 100 a 499 & 7,7 & 8,1 & 8,8 & 8,7 & 10,6 & 11,3 & 9,3 & 10,8 & 13,7 & 10,2 & 9,0 \\
\hline 500 e mais & 91,2 & 90,8 & 89,6 & 89,8 & 87,8 & 86,9 & 88,6 & 86,7 & 83,6 & 87,3 & 88,2 \\
\hline
\end{tabular}

Fonte: Elaboraçáo própria a partir do banco de dados on-line da RAIS/MTE. 
estejam agora se organizando de forma diferenciada, reorganizando-se em termos espaciais, modularizando a produção e fragmentando etapas do processo produtivo.

No caso da região de Campinas, durante a década de I990, houve grande movimento de demissóes no setor metalúrgico, fazendo com que o desemprego se tornasse uma das grandes questôes enfrentadas pelo sindicato.

Segundo Araújo e Gitahy (I998), entre I988 e I998, houve redução de cerca de 30\% do número de empregados no ramo metalúrgico da regiáo. Já o Sindicato dos Metalúrgicos de Campinas e Região contabiliza que, entre 1990 e I999, foram demitidos 8.190 trabalhadores do setor metalúrgico, em dez grandes empresas. Um dos casos mais marcantes de demissóes do período foi o da Mercedes-Benz, que empregava cerca de quatro mil funcionários na planta dedicada à fabricaçáo de ônibus e caminhóes. Entre 1995 e I996, esse número foi reduzido para cerca de mil funcionários (DE SouzA, 2005), e, em I998, a empresa encerrou sua produção de caminhōes e ônibus.

Segundo este último autor, dada a legislação corporativa, os desempregados não puderam ser representados pelo sindicato por não pertencerem ao conjunto de trabalhadores formais, fato que limitou a organização da base para enfrentar as demissóes. Considerando ainda a rotatividade de máo de obra, o sentimento de pertencimento dos desempregados à categoria metalúrgica foi reduzido, fazendo com que se aumentasse a distância do elo que anteriormente os ligava ao sindicato.

Esses movimentos de demissóes em massa parecem ter alcançado fim no ano 2000, quando não houve demissóes de mais de cem funcionários registradas pelo sindicato. Entre 1997 e 2005 , como resultado de políticas de estímulo ao crescimento industrial, segundo a fundação SEADE, foram investidos na regiáo metropolitana de Campinas cerca de I4,3 bilhóes de dólares no setor industrial, o que representou $77,8 \%$ dos investimentos totais na regiáo. Desse último montante, I3,71\% se destinou à indústria automotiva, e somente entre os anos 2003 e 2007 foram investidos cerca de 440 milhóes de dólares na indústria automobilística campineira, em projetos de modernização e ampliação de empresas.

No Gráfico 2 pode-se observar que, a partir do ano de 1998, o número de trabalhadores empregados nessa indústria automobilística tem crescido continuamente, acompanhando o crescimento das atividades da indústria de transformação.

A abertura das plantas produtiva da Honda no ano de 1997, em Sumaré, e da Toyota, no ano de 1998, em Indaiatuba, teve importância central para a retomada dos investimentos no setor automotivo campineiro e na consolidação da região de Campinas como um novo polo de produção, o que criou expectativas com relação à geraçáo de empregos. No entanto, tais expectativas vindas do sindicato e da população em geral foram logo desmistificadas pelo baixo número inicial de cerca de trezentos trabalhadores contratados em cada empresa.

Além disso, a média salarial dos recém-contratados era praticamente metade daquela existente no $\mathrm{ABC}^{8}$, e as exigências no ambiente de trabalho, maiores. Acompanhando o aumento

8 A pesquisa realizada pelo DiEEsE em dezessete municípios com produção automobilística no Brasil revela a diferença de remuneraçóes e poder de compra dos trabalhadores. Mais do que isso, é possível perceber a existência de mercados 


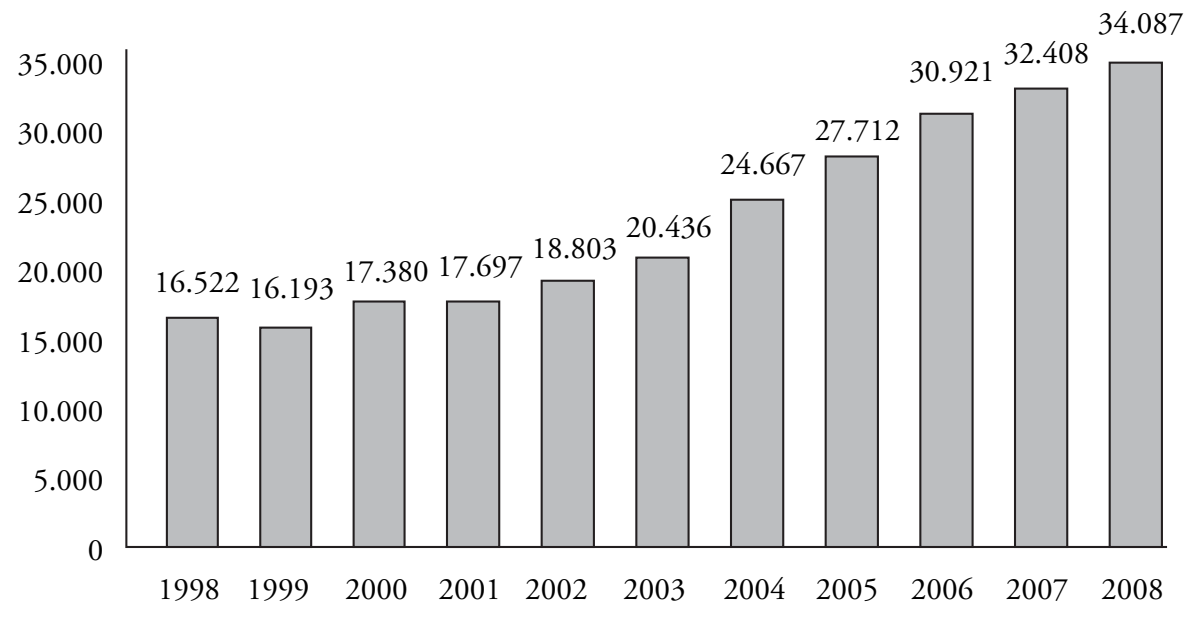

Gráfico 2. Evolução do emprego na indústria automobilística da região metropolitana de Campinas, 1998-2008. Fonte: Elaboração própria a partir do banco de dados on-line da RAIS/MTE.

Tabela 3. Evolução do emprego e taxa de crescimento anual: indústria de transformação e indústria automobilística da regiáo de Campinas, 1998-2008.

\begin{tabular}{ccccc}
\hline & Indústria de transformaçáo & \multicolumn{2}{c}{ Indústria automobilística } \\
\hline Anos & Empregos & $\begin{array}{c}\text { Taxa de crescimento } \\
\text { \% }\end{array}$ & Empregos & $\begin{array}{c}\text { Taxa de crescimento } \\
\text { \% }\end{array}$ \\
\hline 1998 & 146.383 & $-4,7$ & 16.522 & $-5,9$ \\
1999 & 151.880 & 3,7 & 16.193 & -2 \\
2000 & 165.096 & 8,7 & 17.380 & 7,3 \\
2001 & 164.324 & $-0,4$ & 17.697 & 1,8 \\
2002 & 170.255 & 3,6 & 18.803 & 6,2 \\
2003 & 175.986 & 3,3 & 20.436 & 8,6 \\
2004 & 192.373 & 9,3 & 24.667 & 20,7 \\
2005 & 202.984 & 5,5 & 27.712 & 12,3 \\
2006 & 219.216 & 8 & 30.921 & 11,5 \\
2007 & 234.989 & 7,2 & 32.408 & 7 \\
2008 & 239.793 & 2 & 34.087 & 5,2 \\
\hline
\end{tabular}

Fonte: Elaboração própria a partir do banco de dados on-line da RAIs/MTE. 
Tabela 4. Evolução da composição do emprego: indústria automobilística de Indaiatuba 1998-2008.

$1998199920002001200220032004200520062007 \quad 2008$

\begin{tabular}{|c|c|c|c|c|c|c|c|c|c|c|c|}
\hline \multicolumn{12}{|l|}{ Faixa etária } \\
\hline 18 a 29 & 38,1 & 36,6 & 39,5 & 41,2 & 47,1 & 47,0 & 48,3 & 49,2 & 48,6 & 48,3 & 35,1 \\
\hline 30 a 49 & 57,8 & 59,0 & 56,1 & 53,9 & 48,7 & 48,1 & 47,4 & 46,4 & 46,7 & 46,6 & 56,0 \\
\hline 50 ou mais & 4,1 & 4,4 & 4,4 & 5,0 & 4,2 & 4,9 & 4,3 & 4,4 & 4,7 & 5,2 & 9,0 \\
\hline \multicolumn{12}{|l|}{ Sexo } \\
\hline Masculino & 87,1 & 88,2 & 86,8 & 88,6 & 89,6 & 89,1 & 88,3 & 88,6 & 87,3 & 88,1 & 85,0 \\
\hline Feminino & 12,9 & 11,8 & 13,2 & 11,4 & 10,4 & 10,9 & 11,7 & 11,4 & 12,7 & 11,9 & 15,1 \\
\hline \multicolumn{12}{|c|}{ Grau de instruçáo } \\
\hline $1^{\mathrm{a}}$ a $4^{\mathrm{a}}$ série & 17,0 & 14,3 & 11,7 & 10,8 & 7,6 & 7,0 & 4,2 & 3,6 & 3,2 & 2,9 & 6,5 \\
\hline $5^{\mathrm{a}}$ a $8^{\mathrm{a}}$ série & 41,7 & 41,0 & 35,8 & 33,2 & 31,3 & 26,2 & 22,2 & 19,5 & 17,6 & 16,3 & 18,4 \\
\hline $1^{\circ}$ a $3^{\circ}$ colegial & 30,8 & 33,9 & 40,5 & 44,2 & 51,0 & 57,0 & 62,8 & 65,9 & 66,6 & 68,7 & 62,0 \\
\hline Sup. inc. a compl. & 10,6 & 10,9 & 12,0 & 11,8 & 10,2 & 9,7 & 10,8 & 11,0 & 12,5 & 12,1 & 13,0 \\
\hline pós-graduação & 0 & 0 & 0 & 0 & 0 & 0 & 0 & 0 & 0,1 & 0,0 & 0,0 \\
\hline \multicolumn{12}{|l|}{ Porte das empresas } \\
\hline até 99 & 14,4 & 13,2 & 17,4 & 15,0 & 16,7 & 17 & 14,6 & 14,5 & 16,2 & 14,8 & 16,1 \\
\hline 100 a 499 & 49,0 & 51,9 & 32,8 & 13,6 & 30,9 & 30 & 18,0 & 22,5 & 25,4 & 19,1 & 48,0 \\
\hline 500 e mais & 36,6 & 34,9 & 49,8 & 71,5 & 52,4 & 53 & 67,4 & 62,9 & 58,4 & 66,1 & 36,0 \\
\hline
\end{tabular}

Fonte: Elaboraçáo própria a partir do banco de dados on-line da RAIs/MTE

de sua produção, nos anos seguintes, as duas empresas passaram a contratar mais trabalhadores, mas os critérios de contrataçáo de mão de obra - assim como ocorreu de forma generalizada na indústria metalúrgica - passaram a ser mais seletivos em termos de grau de instrução e idade.

$\mathrm{Na}$ Tabela 4, referente ao município de Indaiatuba, com exceção do ano de 2008, é possível verificar que a máo de obra tem se concentrado nas camadas mais jovens, e a participaçáo das mulheres tem se tornado cada vez maior, representando $15 \%$ do total. A mudança mais expressiva, assim como ocorre no $\mathrm{ABC}$, refere-se à elevaçáo da escolaridade dos trabalhadores, em sua grande maioria concentrados atualmente no nível de escolaridade de ensino médio. Em I998, a maioria dos trabalhadores (4I,7\%) possuía ensino fundamental, enquanto em 2008 esse número foi reduzido para $18,4 \%$.

Após essas consideraçóes, procura-se demonstrar quais foram as principais açóes realizadas pelos sindicatos metalúrgicos no $\mathrm{ABC}$ e na região de Campinas, dentro desse contexto explicitado. A partir disso, torna-se possível ressaltar algumas das principais diferenças em suas formas de atuação. Trata-se de dois tipos de organização sindical e de condução de práticas que, em

regionais ou locais que diferem entre si. Os metalúrgicos de São Bernardo do Campo, SP, possuem remuneraçáo I,9 vezes maiores do que os de Indaiatuba (SP) e Sumaré (SP). Fonte: DieEse, CUT-CMN, Sindicato dos Metalúrgicos do $\mathrm{ABC}(2003)$. 
alguma medida, orientam as formas de organizaçáo coletiva de trabalhadores em cada uma dessas montadoras.

\section{AS AÇÕES SINDICAIS NAS REGIÕES DO ABC PAULISTA E DE CAMPINAS}

No $A B C$ paulista, a diminuição de postos de trabalho ilustra o impacto que as mudanças organizacionais tiveram na atividade econômica industrial da regiáo: de um total de 69.154 trabalhadores empregados em montadoras, em janeiro de 1980, o número passou a 31.745, em dezembro de 2002, o que representou a desativaçáo de $55 \%$ dos postos de trabalho no período (Rodrigues; Ramalho, 2007, p. 49). Diante desse cenário, os metalúrgicos do ABC passaram a considerar novas formas de atuação sindical naquele contexto em que demissóes, processos de reestruturaçáo, automatização e desterritorializaçáo das plantas produtivas passavam a ocorrer de forma intensa.

Houve, assim, mudanças na ação sindical, caracterizadas por uma postura de maior negociação com as empresas e com a administraçáo pública da regiáo, criando oportunidades de discutir e de criar mecanismos de participaçáo em políticas públicas e no desenvolvimento econômico.

Em questóes relativas ao trabalho e ao desemprego, podem-se citar alguns exemplos de açóes inéditas por parte do sindicalismo do $\mathrm{ABC}$, como os acordos que reduziram jornadas de trabalho sem redução de salários e também aqueles que permitiram introduzir novas formas de gestão da produção com garantias de postos de trabalho, além das experiências com cooperativas de produção (CONCEIÇÁ̃o, 2008).

A organização por local de trabalho ganha destaque entre os mecanismos de fortalecimento de negociação de interesses, ao abrir possibilidades de modernizaçáo nas relaçôes de trabalho. As comissōes de fábrica, os comitês sindicais de empresa e os delegados sindicais "são vetores incisivos, que apontam para determinado tipo de reforma nessa estrutura, capaz de ampliar os espaços de atuaçáo dos trabalhadores na sociedade brasileira ainda em democratizaçáo" (CARDOSO, 1999, p. 134).

Existentes no $\mathrm{ABC}$ desde 198I, as comissōes de fábrica representaram, sem dúvidas, um avanço nas relaçốes de trabalho, tendo desdobramentos ainda maiores, resultando em um atual modelo "híbrido" de representação sindical. No ano de 1999, as comissōes de fábrica passaram a coexistir com os comitês sindicais de empresa, conforme deliberado no $3^{\circ}$ Congresso dos Metalúrgicos do ABC, no ano de 1996.

Nesse congresso, os trabalhadores realizaram uma proposta integral de reforma estatutária, com finalidade de adequar suas resoluçóes sobre a estrutura organizativa do sindicato. $\mathrm{O}$ objetivo da reforma foi compatibilizar a estrutura do sindicato com a Convenção no ${ }^{\circ}$. 135 da Organizaçáo Internacional do Trabalho (OIT), relativa à proteção dos representantes dos trabalhadores.

Tal reforma foi inspirada na estrutura sindical "orgânica", oriunda do sindicalismo europeu (França, Itália, Espanha e Alemanha). Nesses países, diferentemente do que ocorre no Brasil, o direito à organização no local de trabalho é garantido por lei. Essa reforma estatutária no $\mathrm{ABC}$ 
significou avanços em direção à democratizaçáo da estrutura sindical brasileira, colocando o regime jurídico estabelecido pela CLT em questáo. Além disso, outras questốes referentes à capacidade de mobilizaçấo das bases levaram o sindicato a mudar sua estrutura.

Em alguns casos, preocupadas somente com questôes internas às fábricas, algumas comissóes se tornavam distantes do sindicato. No caso dos comitês sindicais, eles sáo constituídos pelos diretores do sindicato eleitos nas empresas onde exercem suas atividades profissionais, com os votos dos trabalhadores sindicalizados, e o número de membros dos Comitês Sindicais de Empresa corresponde proporcionalmente ao número de trabalhadores sindicalizados em cada empresa. Em suma, os comitês foram criados como uma tentativa de aprimorar a presença do sindicato nos locais de trabalho.

Entre as experiências de participação em políticas públicas, podem ser citadas como mais expressivas as do Consórcio Intermunicipal, Fórum da Cidadania e Câmara Regional do ABC.

O Consórcio Intermunicipal, criado em 1990, foi o primeiro arranjo institucional de caráter regional do $\mathrm{ABC}$, criado como forma alternativa de recuperação política e econômica para resolver problemas em temas como: saúde, transportes, questão ambiental. O Fórum da Cidadania foi criado em 1994 e procurou atuar por meio de grupos temáticos para propor soluçôes para questôes regionais (ConCEIÇấo, 2008). Já a Câmara Regional do Grande ABC foi criada no ano de 1997, constituindo-se em um fórum de debates formado pela associaçáo entre o poder público (governos locais, governo estadual, governo federal e poder legislativo) e a sociedade civil (empresários, sindicatos, ONGs) (Dos ReIs, 2007).

Já o Sindicato dos Metalúrgicos de Campinas e Regiáo (SMRC) atravessou um processo de renovação, após sua diretoria ter sido conquistada pela Oposiçáo Sindical no ano de 1984 . A atividade sindical adotada foi então mais combativa, filiando-se, na época, à corrente Fórum Socialista da CUT. A nova diretoria teve como principais bandeiras o fim do assistencialismo e das contribuições compulsórias, a organizaçáo de base, a democracia colegiada e a liberdade e autonomia na organizaçáo sindical. Conhecido no interior do sindicalismo brasileiro como símbolo de resistência, a entidade se define como um Sindicato "combativo, independente, classista, democrático e organizado pela base" (De SouzA, 2005).

Esse sindicato se opôs firmemente à participação nas Câmaras Setoriais e às tentativas dessa central de negociar com o governo (ARAújo et al., 200I), sendo que em 2007 o SMRC desligou-se da CUT, filiando-se à Intersindical. Pinto (2007) afirma que desde os anos 1980, embora tendendo à negociaçáo por empresa, a grande maioria dos temas tratados pelo sindicato esteve relacionada à questão salarial, às condiçóes de trabalho e à manutenção do emprego. Aspectos relativos às transformaçóes nos processos de trabalho também têm sido negociados, como os planos de cargos e salários e a Participação em Lucros e Resultados (PLR).

Durante a década de 1990, o SMRC atuou também em questôes relacionadas ao desemprego na região, como a montagem de uma associação de trabalhadores com a finalidade de gerir os bens de uma empresa e a tentativa de recuperaçáo de uma fábrica com a criaçáo de uma cooperativa de produção autogestionária. 
Sobre essas experiências, De Souza (2005) identifica que houve contradiçôes entre: a "ofensividade" das reivindicaçóes de caráter político do sindicato e a "defensividade" das reivindicaçôes puramente sindicais e a contradição entre o discurso crítico e a prática de acomodação à estrutura sindical.

No entanto, ao contrário do que ocorre no $\mathrm{ABC}$ paulista desde a década de 1980, até o presente momento quase não há representaçáo interna sindical no interior das empresas do setor metalúrgico na regiáo de Campinas, o que limita as atividades do sindicato para locais externos às fábricas, como os pátios das montadoras. Quanto aos desafios enfrentados pelo SMRC, alguns deles são semelhantes aos existentes no $\mathrm{ABC}$, como constata Pinto (2007): redução de sua base, mediante a intensificação das terceirizaçôes entre 1986-97; elevação geral da escolaridade entre os trabalhadores na regiáo de Campinas; mudanças no perfil etário do trabalhador, agora mais jovem. As práticas sindicais do SMRC estariam, segundo esse último autor, mais relacionadas a questōes referentes ao encolhimento de suas bases, a negociaçốes de salários, jornadas, PLR e intensificação do trabalho.

\section{TRAJETÓRIA EMPRESARIAL E AÇÕES SINDICAIS NA TOYOTA DO BRASIL}

Com a expansáo das atividades da empresa, iniciada em $1950^{9}$, a Toyota passou a exportar caminhôes para outros países da Ásia, como a Coreia, tendo o governo brasileiro, no ano de 1952, encomendado cem caminhóes de grande porte à empresa. Com o crescimento da economia industrial japonesa e em decorrência de pedidos de importação de caminhōes pelo exército norteamericano, a empresa pôde expandir suas atividades, reestruturando plantas e obtendo retorno financeiro. No mesmo ano, a divisão de exportaçáo da empresa (TMS) passou a exportar seus produtos para países como Costa Rica, El Salvador, Venezuela, Colômbia, Peru, República Dominicana, Cuba e Porto Rico.

Em 1955, após concluir que o Brasil poderia ser um país com grande potencial no mercado de veículos, foi enviada uma equipe da empresa ao país para realizar estudos preliminares. Já durante o governo de Juscelino Kubitschek, no ano de 1957, o governo brasileiro criou o Grupo Executivo da Indústria Automobilística (GEIA), responsável por regulamentar as atividades da indústria automobilística no Brasil. Entre as várias medidas, houve restriçôes à importação de veículos, o que acabou culminando na decisão da Toyota de construir uma unidade montadora do veículo Bandeirante na cidade de Sáo Paulo, por meio do sistema Complete Knock-Down (CKD). Em 1962, a empresa inaugurou uma nova unidade produtiva no município de Sáo Bernardo do Campo, também dedicada à produção do Bandeirante.

\footnotetext{
9 No ano de I950, após o Ministry of International Trade and Industry (MrTI), órgão do governo japonês, anunciar seu novo plano de incentivos à indústria automobilística, a Toyota Motors Co. (TMC) criou uma divisáo interna de vendas, a Toyota Motor Sales Co. (TMS), que ficou encarregada das atividades de expansão internacional e exportação de veículos. Fonte: Toyota - A History of the First so Years, Toyota Motor Corporation (1988).
} 
No entanto, segundo a própria empresa, por problemas com fornecedores (a taxa de nacionalizaçáo do veículo era de $60 \%$ ), a qualidade dos automóveis náo correspondeu às expectativas geradas, o que resultou na dificuldade de atender às demandas dos clientes. A empresa passou a ter sérios prejuízos durante anos, havendo a possibilidade de fechamento da unidade - como ocorreu no México, em 1964 -, o que, por decisóes internas, acabou não ocorrendo.

O Brasil foi, portanto, a primeira experiência de montagem de veículos da Toyota fora do Japão, em um primeiro momento não obtendo sucesso em suas atividades. De fato, até o momento do início das atividades de sua segunda planta, no ano de 1998, a Toyota do Brasil esteve à margem de uma disputa pelo mercado interno de veículos e, mais ainda, náo praticou as táo difundidas formas de gestáo toyotistas. Seus principais compradores no ano de 1987 eram empresas de atividades agrícolas e órgáos públicos (respectivamente $35 \%$ e $20 \%$ do total de vendas) ${ }^{10}$.

Entre as montadoras aqui instaladas, somente a Toyota e a Puma náo aderiram ao acordo de Benefícios Fiscais Especiais para a Exportaçáo (Befiex), criado em 1972. Esse programa, voltado para a expansáo das exportaçóes já instaladas, reforçava as barreiras à entrada de novos competidores, implicando no compromisso de exportaçóes acima de quarenta milhóes de dólares anuais por um período de dez anos, em troca de isençáo de taxas de importaçóes de componentes e materiais em até um terço do valor das exportaçôes, entre outros (PosthumA, I99I).

Como já foi dito anteriormente, a Toyota acompanhou os incentivos do NRA e construiu sua segunda planta produtiva no ano de I998, voltada para a produção nacional do veículo Corolla. Além das unidades de São Bernardo e Indaiatuba, a Toyota possui atualmente um escritório administrativo na cidade de São Paulo e um centro de distribuição em Guaíba (RS). A partir do ano de 2003, com a criação de uma organização interna da empresa para integração do gerenciamento na América Latina - a Toyota Mercosul -, as plantas produtivas de Indaiatuba e de São Bernardo consolidaram-se como polos de exportação, inclusive para o México e o Caribe. Atualmente, a empresa possui cerca de 3.300 funcionários (ver Tabela 5), além de investimentos com capital direto em empresas de autopeças. É justamente nesse período que as atividades sindicais na empresa passaram a se consolidar, como será demonstrado adiante.

Até o ano de 1989, praticamente náo havia qualquer tipo de participaçáo do sindicato dentro da Toyota, com exceçáo da Comissáo Interna de Prevençáo de Acidentes (Cipa). Assim como a Toyota parecia ter uma trajetória particular com relação às outras empresas do setor, seus trabalhadores pareciam náo participar das atividades sindicais em curso no $\mathrm{ABC}$. Um dos entrevistados revela:

Em 1989 nós estávamos em uma campanha salarial, as fábricas estavam paradas, a proposta de acordo foi rejeitada, e uma das fábricas que não estavam em greve era a Toyota. E foi feita uma passeata do paço municipal até a Toyota no sentido de pegar todo esse corredor da Avenida Piraporinha e chamar os trabalhadores que estavam trabalhando

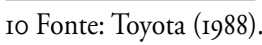


para aderir à greve. Fomos à porta da Toyota, e eles estavam trabalhando. Foram milhares de trabalhadores que ficaram na porta da Toyota, e ela acabou dispensando seus trabalhadores. No que o pessoal desceu aqui essa rua abaixo, começou a haver um confronto entre os trabalhadores e a polícia militar. Até esse momento, o grau de dificuldade de entrar na Toyota era muito grande. A Mercedes parava, a Scania, a Volkswagen, só a Toyota não fazia greve. Esse movimento foi de fora para dentro [...].

A participação começou por volta de 1991, 1992. Através de dois ou três cipeiros que o sindicato começa a levar uma mensagem para dentro da fábrica. Em 1993 a gente consegue eleger um diretor do sindicato dentro da fábrica. A partir da eleição dele dentro da fábrica, começa um processo de aproximação.

No ano de 1996, a planta da Toyota de São Bernardo do Campo, com mais de trinta e quatro anos de existência, passava por um intenso processo de reestruturaçáo produtiva. $\mathrm{O}$ veículo Bandeirante deixaria de ser produzido em breve, havendo até mesmo a possibilidade concreta de desativação dessa planta, uma vez que a nova unidade de Indaiatuba já estava sendo construída. A atuação do Sindicato dos Metalúrgicos do $\mathrm{ABC}$ nesse processo de reestruturação foi decisivo

Tabela 5. Número de funcionários da Toyota do Brasil - 2004-2009.

\begin{tabular}{lcccccc}
\hline & $\mathbf{2 0 0 4}$ & $\mathbf{2 0 0 5}$ & $\mathbf{2 0 0 6}$ & $\mathbf{2 0 0 7}$ & $\mathbf{2 0 0 8}$ & $\mathbf{2 0 0 9}$ \\
\hline Sáo Bernardo do Campo & & & & & & \\
Horistas & 358 & 437 & 539 & 595 & 595 & 584 \\
Mensalistas & 258 & 297 & 334 & 457 & 552 & 594 \\
Total & 616 & 734 & 873 & 1.052 & 1.147 & 1.178 \\
Sáo Paulo & & & & & & \\
Horistas & & - & - & - & - & - \\
Mensalistas & 55 & 72 & 89 & 117 & 116 & 121 \\
Total & 55 & 72 & 89 & 117 & 116 & 121 \\
Indaiatuba & & & & & & \\
Horistas & 1.087 & 1.243 & 1.344 & 1.424 & 1.551 & 1.577 \\
Mensalistas & 214 & 268 & 319 & 376 & 385 & 404 \\
Total & 1.301 & 1.511 & 1.663 & 1.800 & 1.936 & 1.981 \\
Guaíba & & & & & & \\
Horistas & - & 3 & 4 & 5 & 5 & 5 \\
Mensalistas & - & 5 & 6 & 6 & 6 & 6 \\
Total & & 8 & 10 & 11 & 11 & 11 \\
Geral & 1.445 & 1.683 & 1.887 & 2.024 & 2.151 & 2.166 \\
Horistas & 527 & 642 & 748 & 956 & 1.059 & 1.125 \\
Mensalistas & 1.972 & 2.325 & 2.635 & 2.980 & 3.210 & 3.291 \\
Total & & & & &
\end{tabular}

Fonte: Anfavea. Dados náo publicados. 
para que a unidade de Sáo Bernardo continuasse em atividade, o que foi a principal tarefa das negociaçôes que ocorreram ao longo de três anos.

Sobre a participaçấo do sindicato dentro da empresa, um dos entrevistados considera:

A partir de 1990, 199I, a partir desse momento da CIPA, o sindicato começa a entrar na fábrica. Em 1993, a gente consegue eleger um diretor do sindicato dentro da Toyota, e partir daí se tem um processo melhor. A Toyota não chegou a ter Comissão de Fábrica, como aconteceu na Scania, na Ford, na Mercedes. A Toyota passou a ter uma Cipa que tinha um espaço, e, a partir de 1996, o sindicato faz uma mudança na sua estrutura de comitês sindicais dentro da fábrica. É nesse processo que a Toyota elege três pessoas para compor o comitê sindical da empresa. Então, ela não passou por um processo de comissão de fábrica, ela passa por um processo onde a comissão interna é de diretores do sindicato. Isso foi uma mudança da estrutura do sindicato.

Segundo essa fala, podemos observar que a relação entre sindicato e empresa na Toyota era bastante restrita, e as relaçôes de trabalho eram fortemente controladas, não havendo representaçáo sindical interna na fábrica, o que motivou a criação de um grupo oficial de trabalhadores ligados ao sindicato. A criação do comitê em 1994 e sua formalização em 1996 resultaram em um inédito avanço nas relaçôes de trabalho nessa unidade, expressando, ainda que tardiamente, a tendência à mobilização e à organização dos trabalhadores nos locais de trabalho. Ao mesmo tempo, em 1996 passou a ocorrer o processo de reestruturação produtiva da planta, que foi acompanhado pelo sindicato pela nomeaçáo de um representante.

Ao mesmo tempo, outro entrevistado ressalta que a unidade produtiva sofria de problemas relacionados à defasagem de sua infraestrutura, repercutindo sobre as condiçóes de trabalho. $\mathrm{Ou}$ seja, as formas de gestâo "toyotistas", discutidas táo intensamente pelos estudiosos durante as décadas de 1980 e 1990, em nível internacional e no Brasil, náo ocorriam, na prática, na Toyota de São Bernardo do Campo.

Essa reestruturaçáo foi importante, segundo o entrevistado, porque tornou a relaçáo entre empresa e sindicato mais próxima para formular negociaçôes que contemplassem as reivindicaçôes dos trabalhadores, assegurando postos de trabalho. Mesmo havendo demissóes e o risco do fechamento da unidade de Sáo Bernardo do Campo em decorrência da criaçáo da planta de Indaiatuba, a reestruturaçáo pode ser considerada um momento central para a atividade sindical na Toyota:

Então, do ponto de vista histórico nosso com a empresa foi esse: a reestruturação por qual a empresa teve que passar aproximou as discussóes entre sindicato e empresa. Isso também trouxe uma garantia aos trabalhadores de que o sindicato estava presente e de que não deixaria acontecer o pior, que seria o fechamento da unidade. [...] Então, por isso eu te digo: a reestruturação foi importante, as conquistas ao assumir foram impor- 
tantes, hoje a Toyota emprega mil e duzentos trabalhadores aqui, o diretor da empresa responsável que liderou esse processo e o nosso sindicato e o dirigente do sindicato que liderou o processo foram responsáveis pelo êxito. Por isso que eu falo que avançou consideravelmente; não se compara com a Toyota de 1990 o que se tem hoje.

A confirmação dos investimentos da Toyota em uma nova unidade produtiva em Indaiatuba foi feita no ano de 1996, quando a empresa iniciou o processo de reestruturaçáo de sua unidade em São Bernardo do Campo. Inicialmente, como foi apontado, havia dúvidas sobre o destino dessa antiga fábrica, havendo até mesmo a possibilidade de fechamento. A chegada da Toyota e da Honda no intervalo de dois anos consolidou a região de Campinas como uma nova regiáo industrial do setor automotivo, criando expectativas com relaçáo à geração de empregos. Isso pode ser ressaltado pelo fato de que, em I997, a Mercedes-Benz, entáo principal empresa automobilística do município de Campinas, instalada em I979, anunciou a criaçáo da nova unidade da empresa em Juiz de Fora (MG), o que culminou na desativação de sua produção de caminhóes.

Em um primeiro momento, no início de suas atividades, a empresa contratou cerca de seiscentos funcionários para a produção do Corolla. Com o relativo sucesso das vendas desse modelo no mercado interno, houve o aumento gradual da produção, acarretando contrataçóes diretas no quadro de funcionários da empresa.

A entrevista a seguir, com o dirigente sindical do Sindicato dos Metalúrgicos de Campinas e Região, procura demonstrar a formação de um novo contingente de trabalhadores operários e as açóes sindicais desenvolvidas pela entidade nesse novo contexto de abertura de novas unidades de produção. Essas novas unidades, tanto da Honda como da Toyota, caracterizaram-se por serem fábricas "enxutas", ou seja, traduziam-se, no plano produtivo, pela dinâmica de cadeias regionais e globais, visando à maior produtividade. Já no plano organizacional, as formas de gestáo correspondiam às recentes estratégias que privilegiam o envolvimento do trabalhador.

Como revela o dirigente sindical, os primeiros anos de atividade da unidade de Indaiatuba foram bastante conflitivos, tendo em vista as condições de trabalho bastante intensas e com remuneraçóes muito abaixo do que era esperado.

Nesse sentido, a greve ocorrida em 3 de novembro de 1999 é considerada pelo sindicato campineiro um marco em sua atuação, mesmo que não tenha conseguido se prolongar por muito tempo, em razão da forte pressão exercida pela empresa.

As principais açóes do Sindicato dos Metalúrgicos de Campinas e Região puderam ser resumidas na fala do dirigente sindical entrevistado, na qual são ressaltados os principais resultados positivos das negociaçóes desde I999, envolvendo principalmente questóes referentes à jornada de trabalho, à PLR e aos salários. Essas consideraçóes são importantes para constatar que houve uma ampliação na atuação do Sindicato dos Metalúrgicos de Campinas e Região. Trata-se de um contexto social distinto daquele verificado em Sáo Bernardo do Campo, em que as condiçóes de trabalho se apresentavam melhores para os trabalhadores, os salários eram superiores, havia representação sindical interna, além de outros benefícios. 
A Toyota veio no sentido de reduzir custos, de pagar baixos salários, de trabalhar 44 horas semanais. Com a atuação do sindicato, conseguimos reduzir a jornada para 40 horas; a empresa não tinha política de cargos e salários, e hoje tem. Na política de cargos e salários, o trabalhador entra na empresa e, durante cinco anos, ele tem um aumento de 3,5\%, até chegar num teto. Daí uma luta de vários meses de discussão que tivemos que fazer vários protestos, comunicados de greve. Então, o trabalhador tem aumento automático a cada seis meses, independentemente da chefia. Os PLRs; existe uma disputa muito pesada na concepção da PLR. Porque nós não discutimos PLR com metas, porque as metas já estáo incluídas na produção em si. Porque toda empresa tem a sua meta de quanto vai produzir por dia, por mês, por ano. E o trabalhador entende isso. Foram várias conquistas nesse sentido, e estamos hoje aí para manter políticas de cargo e salário, redução da jornada, PLR, que a gente conseguiu aumentar; hoje é um dos melhores da região e sem metas.

Durante a semana, que ocorreu a greve de 1999, a empresa fez uma proposta que atendia somente ao aumento dos salários, 6\% de reposição da inflaçáo e R $\$$ I.Ioo,oo de Participaçáo em Lucros e Resultados (PLR). Essa proposta foi rejeitada pelos trabalhadores em assembleia geral, mas, dias depois, as atividades na fábrica foram retomadas, finalizando a greve. Sobre esse acontecimento, o entrevistado afirma:

Nós tivemos a greve em 1999, que foi uma greve que, por parte da empresa, ela buscava o trabalhador em casa, ligava para a família, ligava para a mãe, criou toda uma situação em que o cara chegava em casa, e a própria mãe mandava o cara pra fábrica. Ela mudava o trajeto do ônibus. Foi uma guerra mesmo, tanto é que nós não conseguimos segurar a paralisação. O pessoal sabia o que queria, mas a pressão familiar estava maior do que aquilo o que estávamos almejando como nosso objetivo, que era o salário. Então, nesse período, a Toyota teve uma luta intensa com o sindicato. [...] A Toyota percebeu que aquela guerra não ia levar a lugar nenhum e acabou mudando a sua postura. Eles mudam a postura, mas tentam ganhar o trabalhador de outra forma. Como eu falei para você, eles começaram a copiar tudo do sindicato: "o sindicato tem um clube de campo? Vamos fazer um clube de campo". Às vezes tinha uma atividade do sindicato no fim de semana, um curso de formação, eles arrumavam um torneio [....]

A Toyota é uma empresa que, quando começou, teve uma disputa com o sindicato. Disputa no sentido de ganhar os trabalhadores. Tanto é que a gente tinha um clube de campo onde os trabalhadores passavam o final de semana, e a empresa copiou tudo o que a gente tinha, no sentido de, em vez de ir pro clube do sindicato, vem para cá. Criou todas as condiçóes para que as pessoas ficassem os dias de semana na fábrica e no final de semana fosse para lá. 
A disputa da empresa com o sindicato hoje não é tão intensa, segundo o entrevistado. No entanto, a empresa tem procurado outras formas de atuação, como certo tipo de controle que restringe a atividade sindical no interior da fábrica. Um dos grandes avanços na organizaçáo coletiva no movimento sindical brasileiro, especialmente durante a década de I980, foi a criaçăo das comissões internas de fábrica, forma institucional de fazer expressar suas reivindicaçôes, o que significa uma real diminuiçáo do poder gerencial, aumentando o poder de controle dos trabalhadores sobre as condiçôes de trabalho (RoDRIGUES, I99I).

$\mathrm{Na}$ unidade da Toyota de Indaiatuba não há comissão interna de fábrica, o que, para alguns autores, pode representar uma dificuldade nas negociaçōes com a empresa (ARAÚjo; GITAHY, I998; PINTO, 2007). Sobre essa questấo o entrevistado comenta o seguinte:

Muitas empresas têm comissão de fábrica, mas nós não queremos uma comissão de fábrica para discutir quem vai ser mandado embora e quem entra. Nós queremos uma comissão de fábrica para atuar. Nós colocamos isso em pauta várias vezes, tanto na Toyota como na Honda. Em Sáo Bernardo, por exemplo, tem comissão que vai discutir os interesses da empresa, saber quem vai ser mandado embora e quem não vai. Para nós não interessa isso, queremos uma comissão de fábrica que atue politicamente, que vai buscar benefício para os trabalhadores.

Para o entrevistado, no entanto, a ausência de representação sindical no interior da fábrica não impede a mobilizaçáo coletiva dos trabalhadores nos próprios locais de trabalho:

Como é uma empresa que teve muitas lutas no início, porque trabalhávamos 44 horas, hoje trabalhamos 40, o PLR era pouco, hoje é um dos maiores da regiáo, então, a pessoa, quando está chegando, sempre vai encontrar alguém que participou dessas lutas. Então, é muito fácil em uma empresa que tem cerca de $70 \%$ dos trabalhadores sócios do sindicato. [...] A gente costuma dizer o seguinte: todas as empresas têm aquilo o que a gente chama de pelego. Mas quem está do lado do sindicato está do lado do sindicato, quem não está permanece do outro lado. Porque os trabalhadores no passado participaram de muitas lutas e tiveram conquistas. Entáo, quando o trabalhador chega, os próprios trabalhadores já chegam junto, dizendo: "Você vai ficar sócio do sindicato?". Ou seja, existe muito essa parte organizativa. No passado era pior ainda, por parte dessas lutas, o pessoal era muito radical. Hoje em dia năo é assim, a pessoa tem que ficar sócia do sindicato por uma questão de consciência. Entáo, os próprios trabalhadores procuram organizar os que estão chegando.

Entre as principais pautas atuais dos trabalhadores no sindicato, diz o entrevistado que a questâo do ritmo de trabalho intenso tem sido bastante discutida. As doenças ocupacionais também são ressaltadas como um dos problemas centrais nas condiçôes de trabalho na unidade de 
Indaiatuba. O ritmo de trabalho intenso, segundo o dirigente sindical, também trouxe mudanças na organização do trabalho, em que a prioridade é exclusivamente a produção:

No começo, quando o trabalhador entrava na Toyota, ele chegava a ficar duas semanas numa sala, fazendo treinamento. Mas essa situação diminuiu hoje, está em torno de três dias. A ideia aí é construir o que eles chamam de integração. Uma vez por mês tem uma parada de meia hora para falar de segurança, mas do jeito dela. Como lá passa muita empilhadeira, tem a faixa de pedestre. No passado, se passava um pedestre, a empilhadeira parava. Hoje já tem uma diferença. A preferência é de quem está na produção, a empilhadeira; então, se você está andando, você tem que parar e olhar. É o inverso do que ela defendia antes, porque o objetivo é produzir o carro. Se você está andando, você não está produzindo.

\section{CONCLUSÕES}

Os dados obtidos até o presente momento permitem concluir que, no caso do ABC paulista, a mudança de atuaçáo nas práticas sindicais observada é traduzida pela adoção de uma postura de maior negociação com as empresas, pela renovaçáo de sua estrutura de representação e por maior participação em questốes econômicas e sociais junto aos órgãos de administração pública. Isso foi expresso, por exemplo, a partir de experiências como a Câmara Setorial Automotiva, a Câmara Regional do Grande ABC, a participação do sindicato no Planfor.

Com relaçáo às negociaçóes por empresa, observa-se que houve uma renovação na atuaçáo sindical na Toyota no ano de 1996, quando o processo de reestruturaçáo produtiva teve início na unidade de São Bernardo do Campo. O avanço nas negociaçóes entre sindicato e empresa possibilitou a criaçáo de uma comissáo interna de fábrica, além de assegurar a permanência dessa planta na regiáo, hoje dedicada à fabricação de componentes para a unidade de Indaiatuba e também para o exterior.

No caso de Indaiatuba, constatou-se que a postura mais "combativa" do sindicato metalúrgico desde 1984 foi bastante distinta daquela existente no $\mathrm{ABC}$, rejeitando, por exemplo, sua participaçáo nas Câmaras Setoriais. A chegada da Toyota à região de Campinas trouxe, inicialmente, uma expectativa com relaçáo à geraçáo de novos empregos. Essas expectativas foram logo sendo desmistificadas por práticas de contrataçáo, salários e jornada de trabalho que desapontavam os trabalhadores e o sindicato metalúrgico, especialmente quando comparadas à realidade vivida em São Bernardo do Campo.

Nesse caso, observou-se, a partir da fala dos entrevistados, que, a partir de 1999, houve mudanças significativas na ação sindical, período em que ocorreu a primeira greve dos trabalhadores da unidade de Indaiatuba. Essa greve revelou a possibilidade de questionar as condiçóes de trabalho e reivindicar melhorias nos salários dos trabalhadores. Mais do que isso, é possível 
verificar que a greve de 1999 representou a capacidade coletiva de organização dos trabalhadores, ainda que eles não possuam representação sindical interna de fábrica.

E, se, por um lado, a abertura da planta da Toyota em Indaiatuba, no ano de 1998, concretizou-se, motivada pela busca da empresa por redução de custos na produção e pelo recrutamento de trabalhadores com pouca participação sindical, a atuação do sindicato metalúrgico de Campinas desde entáo vem se fortalecendo.

Dessa forma, argumenta-se que, apesar da tendência ao estreitamento das bases dos sindicatos metalúrgicos verificada durante a década de 1990 e da mudança no perfil dos trabalhadores metalúrgicos, isso não significa, em dias atuais, o enfraquecimento da ação sindical, mas, sim, a consolidação de uma tendência à microrregulação nas relaçôes de trabalho.

De forma geral, as novas formas de atuação dos sindicatos revelam um crescimento qualitativo de prática sindical metalúrgica em dias atuais. Já nas duas unidades produtivas verificadas, as açôes sindicais nấo necessariamente representam açôes sindicais inéditas, mas o ineditismo parece, sim, residir em maior diálogo com a empresa, tornando possível atender às reivindicaçôes dos trabalhadores.

Do ponto de vista das relaçôes de trabalho socialmente construídas, trata-se, então, da existência de práticas distintas em São Bernardo do Campo e em Indaiatuba. Apesar das diferenças regionais, salariais, de tempo de empresa e experiência em organizaçáo sindical, tais práticas distintas, no limite, tornam-se similares, quando consideradas com a fala dos entrevistados, pois buscam contornar os desafios trazidos aos sindicatos por um novo contexto da indústria automobilística brasileira.

\section{REFERÊNCIAS BIBLIOGRÁFICAS}

Abreu, Alice; Rangel, Paiva; Ramalho, José Ricardo. Reestruturação produtiva, trabalho e educação. Os efeitos sociais do processo de terceirização em trếs regióes do país. O caso do Rio de Janeiro. 1998. Relatório (Pesquisa).

Anderson, Patrícia. Câmaras setoriais. Histórico e acordos firmados - 1991/95. Rio de Janeiro: Ipea, 1999.

Anfavea. Anuário Estatístico. Anfavea, São Paulo, 2006. Anuário Estatístico. Anfavea, São Paulo, 2007. Anuário Estatístico. Anfavea, São Paulo, 2008.

AraúJo, Ângela Maria Carneiro; GITAHY, Leda. Reestruturação produtiva e negociaçóes coletivas entre os metalúrgicos paulistas. In: Congresso Internacional da Latin American Studies Association, 21. Anais... Chicago, 1998. 
Araújo, Ângela M. Carneiro; Cartoni, Daniela M.; Justo, Carolina R. D. Mello. Reestruturação produtiva e negociação coletiva nos anos 90. Revista Brasileira de Ciências Sociais, [S.1.], Associação Nacional de Pós-Graduação em Ciências Sociais (Anpocs), v. 16, n. 45, p. 85-112, fev. 2001.

Araújo, Sílvia (Org.). Trabalho e capital em trânsito: a indústria automobilística no Brasil. Curitiba: Ed. UFPR, 2007.

Arbix, Glauco. A câmara banida. In: Arbix, G.; Zilbovicius, M. (Org.). De JK a FHC: a reinvenção dos carros. São Paulo: Scritta, 1997. pp. 471-502.

Políticas do desperdício e assimetria entre público e privado na indústria automobilística. Revista Brasileira de Ciências Sociais, Rio de Janeiro, v. 17, n. 48, pp. 109-129, 2002.

Arbix, Glauco; Zilbovicius, Mauro. (Org.). De JK a FHC: a reinvenção dos carros. São Paulo: Scritta, 1997.

BedÊ, Marco Aurélio. A política automotiva nos anos 90. In: Arbix, G.; Zilbovicius, M. De JK a FHC - A reinvenção dos carros. São Paulo: Scritta, 1997.

Bernardes, Roberto. Novas tecnologias e modernização conservadora na indústria brasileira. Sáo Paulo em Perspectiva, v. 5, n. 3, pp. 62-69, jul./set. 1991.

BNDES. Panorama do setor automotivo. Informe Setorial, Área industrial, n. 9, Brasília, dezembro 2008.

Bresciani, Luís Paulo. Na zona do agrião: a nova agenda da negociação coletiva. In: Zilbovicius, Mauro; Arbix, Glauco. De JK a FHC: a reinvenção dos carros. São Paulo: Scritta, 1997. p. 257.

Burawoy, Michael. The politics of production. Londres: Verso, 1985.

Cardoso, Adalberto Moreira. Sindicatos, trabalhadores e a coqueluche neoliberal: a Era Vargas acabou? 1. ed. Rio de Janeiro: Ed. FGV, 1999.

- Trabalhar, verbo transitivo: destinos profissionais dos deserdados da indústria automobilística. Rio de Janeiro: Ed. FGV, 2000.

Cardoso, Adalberto Moreira; Comin, Álvaro; Campos, André. As bases sociais do sindicalismo metalúrgico. In: Arbix, Glauco; Zilbovicius, Mauro (Org.). De JK a FHC: a reinvenção dos carros. São Paulo: Scritta, 1997. pp. 413-448.

Castro, Nadya Araújo (Org.). A máquina e o equilibrista. 1. ed. São Paulo: Paz e Terra, 1995.

Conceição, Jefferson José. A indústria de autopeças do ABC sob o turbilhão micro e macroeconômico da década de 1990. In: Rodrigues, Iram Jácome; Ramalho, José Ricardo 
(Org.). Trabalho e sindicato em antigos e novos territórios produtivos. Comparaçôes entre o ABC paulista e o Sul Fluminense. Sáo Paulo: Annablume, 2007.

Quando o apito da fábrica silencia: sindicatos, empresas e poder público diante do fechamento de indústrias e da eliminação de empregos na Região do ABC. ABCD Maior, 2008.

De Souza, Davisson Charles Cangussu. Sindicato dos Metalúrgicos em Campinas e região diante do desemprego no periodo de 1990 a 2002. 2005. 195 p. Dissertação (Mestrado em Sociologia) - Universidade de São Paulo, São Paulo, 2005.

Dieese, Cut-Cmn, Sindicato dos Metalúrgicos do Abc. Do holerite às compras: remuneração, preços e poder aquisitivo do tempo de trabalho em 17 municípios com produção automobilística no Brasil. São Paulo: SMABC, 2003.

Dos ReIs, Regina. Novas experiências da articulação política regional no Grande ABC paulista. In: Rodrigues, Iram Jácome; Ramalho, José Ricardo. Trabalho e sindicato em antigos e novos territórios produtivos. Comparaçóes entre o ABC paulista e o Sul Fluminense. São Paulo: Annablume, 2007.

Garcia, Sandro Ruduit. Global e local: o novo pólo automobilístico de Gravataí e suas implicaçôes sociais e políticas. 2006. 386 p. Tese (Doutorado), UFRGS, Porto Alegre, 2006.

Gitahy, Leda; Bresciani, Luís Paulo. Reestruturação produtiva e trabalho na indústria automobilística brasileira. Texto para Discussão, Campinas, DPCT/IG/Unicamp, n. 24, 1998.

Hirata, Helena. Sobre o “modelo” japonês. São Paulo: Edusp, 1993.

Hyman, Richard. Os sindicatos e a integração econômica européia. Revista Latino-Americana de Estudos do Trabalho, São Paulo, Alast, ano 3, n. 5, 1997.

IpeA. Conjuntura macroeconômica. Mercado de Trabalho - Conjuntura e Análise, n. 3, Brasília, jan. 1997.

Leite, Márcia de Paula; Rizek, Cibele. Cadeias, complexos e qualificaçóes. In: Encontro LatinoAmericano de Sociologia do Trabalho, 2. Anais... São Paulo, Águas de Lindóia, 1997.

Lima, Eurenice Oliveira de. Toyota: a inspiração japonesa e os caminhos do consentimento. In: Antunes, Ricardo (Org.). Riqueza e miséria do trabalho no Brasil. 1. ed. São Paulo: Boitempo Editorial, 2006. v. 1. pp. 115-145.

Pialoux, Michel; Beaud, Stéphane. Retorno à condição operária. São Paulo: Boitempo, 2009.

Pinto, Geraldo Augusto. O Sindicato dos Metalúrgicos de Campinas e a reestruturação produtiva do setor de autopeças. In: Congresso Brasileiro de Sociologia, 13. Anais... Recife, 2007. 
Posthuma, Anne Caroline. Changing production practices and competitives strategies in the Brazilian auto components industry. 1991. Tese (Doutorado) - IDS/University of Sussex, Brighton, 1991.

Rodrigues, Iram Jácome. Comissão de fábrica e trabalhadores na indústria. São Paulo: Cortez; Fase, 1991.

Comissóes de fábrica e reestruturação produtiva. In: Arbix, Glauco; Zilbovicius, Mauro (Org.). De JKa FHC: a reinvenção dos carros. São Paulo: Scritta, 1997. pp. 237-256.

- Um laboratório das relaçóes de trabalho: o ABC paulista nos anos 90. Tempo Social, São Paulo, v. 14, n. 1, pp. 137-157, maio 2002.

Rodrigues, Iram Jácome; Martins, Heloísa de Souza. O sindicalismo brasileiro na segunda metade dos anos 90. Tempo Social; Rev. Sociol., USP, São Paulo, v. 11, n. 2, pp. 155-182, out. 1999 .

Rodrigues, Iram Jácome; Ramalho, José Ricardo (Org.). Trabalho e sindicato em antigos e novos territórios produtivos. Comparaçóes entre o ABC paulista e o Sul Fluminense. Sáo Paulo: Annablume, 2007.

Rodrigues, Leôncio Martins. Destino do sindicalismo. São Paulo: Edusp, 1999.

Salerno. Mário Sérgio. Trabalho e organização na indústria integrada e flexível. In: Ferreti, Celso J. et al. Novas tecnologias, trabalho e educaçâo: um debate multidisciplinar. Petrópolis: Vozes, 1994.

Toyota. Toyota - A History of the first 50 years. Toyota Motor Corporation, 1988. . Toyota. Material de divulgação. São Bernardo do Campo: Toyota do Brasil SA, 1998.

Zilbovicius, Mauro. Modelos para a produção, produção de modelos: gênese, lógica e difusão do modelo japonês de organização da produção. São Paulo: Ed. Annablume/FAPEsP, 1999.

Werneck, Dorothea; Gonçalves Jr., Carlos Augusto; Vaz, Cláudio; Oliveira, Francisco. Câmaras setoriais: a experiência do setor automobilístico. Cadernos de Pesquisa, São Paulo, Cebrap, n. 1, 1994. 